\title{
Habitat fragmentation and primate conservation in the Atlantic Forest of eastern Minas Gerais, Brazil
}

\author{
Stephen F. Ferrari and Vânia H. Diego
}

\begin{abstract}
Reduced to a tiny fraction of its original area, much of the Atlantic Forest habitat remaining in eastern Brazil is distributed in small, isolated patches on private land. The potential role of these fragments in the conservation of the region's primate fauna is poorly understood. As part of a study of buffy-headed marmosets Callithrix flaviceps in Minas Gerais, forest remnants were visited in order to evaluate this potential. Marmosets were observed in one-third of the sites and may exist in up to 60 per cent of forest patches in the region. A second threatened primate, the brown howler monkey Alouatta fusca, may occur in one-quarter of the sites visited. The muriqui Brachyteles arachnoides was not encountered. Overall, the survey suggests that, with appropriate management, privately owned forest fragments may play an increasingly important role in the conservation of the Atlantic Forest's fauna in this and other regions.
\end{abstract}

Endemic to a relatively small region of the Atlantic Forest of the Brazilian states of Espírito Santo and Minas Gerais (Hershkovitz, 1977; Ferrari and Mendes, 1991; Mendes, 1993), the buffy-headed marmoset Callithrix flaviceps is one of the most endangered of Neotropical primate species. Ferrari and Mendes (1991) confirmed its occurrence in nine municipalities of the two states, although only five populations are known to exist in officially protected areas, all in Espírito Santo. However, Mendes (1993) was unable to confirm the presence of Callithrix in the Caparaó National Park, the region's largest protected area.

Unlike lion tamarins, Leontopithecus spp., endangered Atlantic Forest callitrichids for which a captive-breeding programme is well established (Kleiman et al., 1988), C. flaviceps is virtually unknown in captivity, and conservation efforts must concentrate on populations existing in the wild. This species also contrasts with lion tamarins in being specialized for the dietary exploitation of plant gums. Its ability to substitute systematically gum for fruit as a source of carbohydrates during periods of fruit scarcity, enables it to achieve higher population densities than lion tamarins (Rylands, 1989) and to colonize marginal and disturbed forest habitats where edible fruit may be relatively scarce during most of the year (Ferrari, 1991). This enables C. flaviceps to survive in small patches of highly disturbed habitat, an important factor for the conservation of the species (Ferrari and Mendes, 1991).

Of the three other primate species that occur in the study area (Figure 1), two (the muriqui Brachyteles arachnoides and the brown howler monkey Alouatta fusca) are also endemic to the Atlantic Forest and, like the buffy-headed marmoset, are seriously threatened by habitat loss (Mittermeier et al., 1982). Both species have far more extensive geographical ranges than $C$. flaviceps, although their significantly larger body size $(5-15 \mathrm{~kg}$ compared with 0.4 $\mathrm{kg}$ ) also makes them far more susceptible to both hunting and habitat fragmentation. The region's fourth primate species, the tufted capuchin Cebus apella, is the most adaptable and widespread primate in the Neotropics. Nevertheless, the subspecies found in eastern 


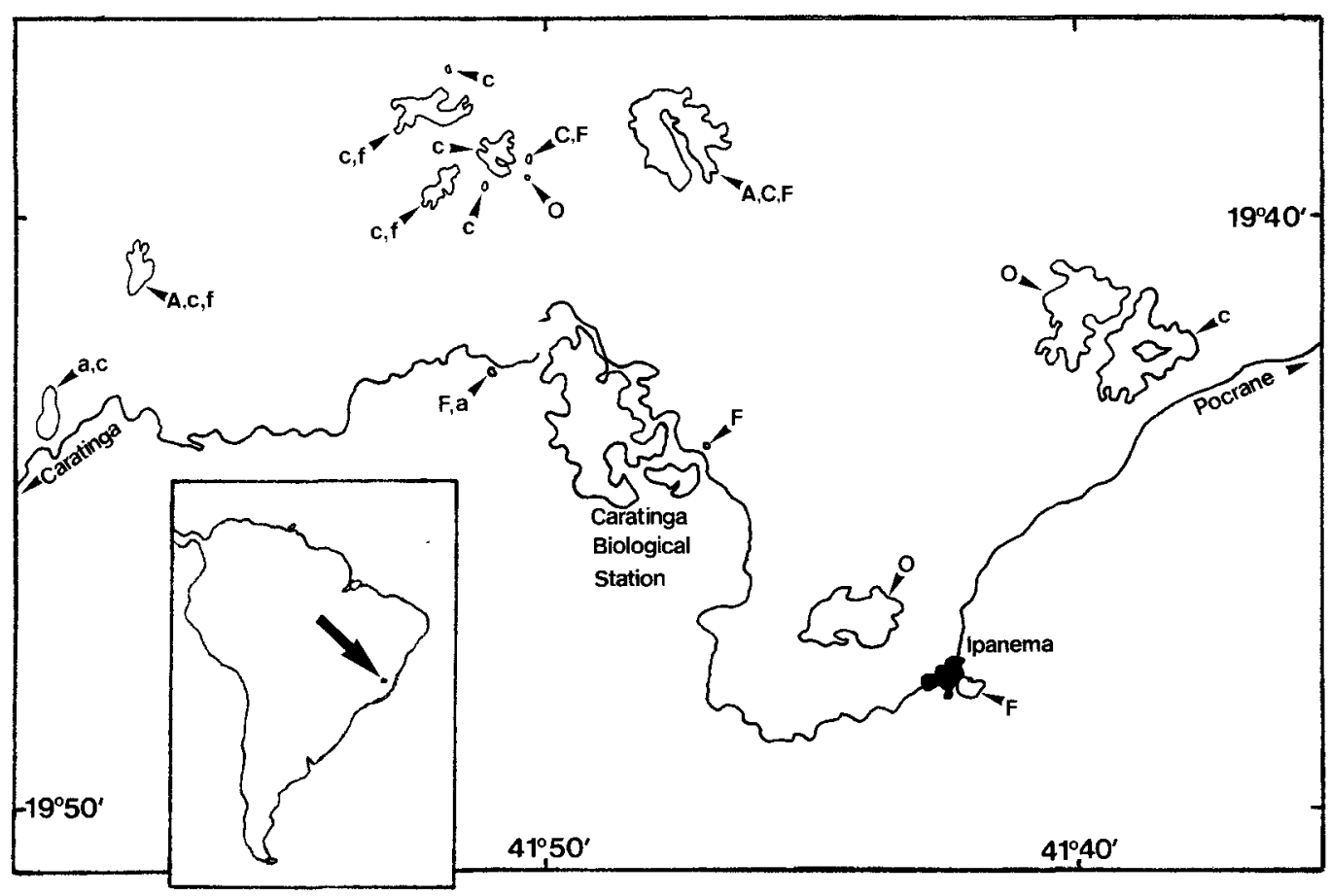

Figure 1. Map of the study area showing the forest remnants visited in the vicinity of the Caratinga Biological Station. A, Alouatta fusca sighted; a, A. fusca reported; C, Cebus apella sighted; c, C. apella reported; F, Callithrix flaviceps sighted; $\mathrm{f}, \mathrm{C}$. flaviceps reported; $\mathrm{O}$, no primates reported or sighted.

Minas Gerais, C. a. nigritus, is also potentially threatened by habitat loss and hunting, in particular as an agricultural pest. The two remaining Atlantic Forest genera, Callicebus and Leontopithecus, are not known to occur in the study area.

\section{Primate populations in eastern Minas Gerais}

Apart from the Caparaó National Park, from which marmosets are apparently absent (Mendes, 1993), there are no officially protected areas in the municipalities of eastern Minas Gerais in which C. flaviceps is known to occur. One of the largest and best known forest fragments in this region is the 800-ha Caratinga Biological Station on the Fazenda Montes Claros, where muriquis, brown howlers and buffy-headed marmosets have all been the subjects of long-term ecological studies over the past decade (Mendes, 1989; Ferrari, 1991; Strier, 1991a).

Between July 1990 and July 1991, 16 forest fragments within a radius of $20 \mathrm{~km}$ of the Caratinga Biological Station in the municipalities of Caratinga and Ipanema were surveyed with the principal objective of locating populations of $C$. flaviceps and recording the presence of this and other Atlantic Forest primates in the region's forest remnants (see Diego et al., 1993).

The survey was based on systematic interviews with the owner or administrator of each site, followed by one or more visits to the forest remnant to confirm the existence - or otherwise - of primate populations. Specific information collected during the interviews included the size of the forest (remnants varied in size between 14 and 216 ha), the species of primate that were known to occur, the existence of activities such as hunting and logging, and attitudes towards the conser- 
vation of local fauna. During visits to forest patches, confirmation of the presence of $C$. flaviceps was facilitated by playing tape recordings of marmoset calls.

Primates were reported and/or observed at 13 of the 16 sites visited (Figure 1). Marmosets were reported at eight sites and observed at five sites, including two at which primates had not been reported in interviews. Capuchins were reported at nine sites, although only observed at two of these. Howler monkeys were reported at four sites and confirmed at two of these, while muriquis were neither reported nor observed.

Most forests were associated with freshwater springs, reflecting their owners' recognition of their value for the protection of these important resources. The protection of the forest itself and its fauna is a different matter, however. One-third of the interviewees reported that hunting occurred and logging took place in at least two of the sites. The extraction of firewood is universal. While marmosets are seldom, if ever, targeted by hunters, the large-bodied howlers and muriquis are valued game, and hunting has probably been an important factor in their almost complete disappearance within the region. Capuchins were frequently treated as agricultural pests.

\section{Forest patches and primate conservation}

In general, large reserves are better than small ones because they will usually support more complete and viable populations of a region's fauna and flora (Diamond, 1975; Soulé and Simberloff, 1986). However, for many ecosystems, such as Brazil's Atlantic Forest, conservation strategies are moulded by the availability of sites, many of which will be suboptimal in terms of size and the amount of habitat degradation.

The current study area in eastern Minas Gerais, where the biggest remnants of native forest habitat are already too small to support the region's largest native birds and mammals, is typical. Nevertheless, even the smallest sites may be a valuable potential resource for the conservation of certain species over the long term (Ferrari and Mendes, 1991).

New World primates are especially vulnerable to habitat fragmentation because of their degree of arboreal specialization. Even the largest species appear unable to traverse the distances that separate major forest fragments. This implies two major problems: an inability to recolonize forest patches, however large, in which populations have been eliminated and the absence of gene flow between populations that do exist.

Lying in the rain shadow of the Mantiqueira range, whose peaks include, at Caparaó, the highest in South America east of the Andes and south of the Amazon, the climate of eastern Minas Gerais is dry and seasonal in comparison with the neighbouring coastal states of Espírito Santo and Rio de Janeiro. This is reflected in both significant habitat differences (Hueck, 1972) and the seasonality of fruit production (Ferrari, 1991; Strier, 1991a). These factors may explain why the region contains only four of the Atlantic Forest's six genera of primates.

Like C. flaviceps, A. fusca and B. arachnoides are able to endure fruit scarcity through the exploitation of alternative resources, in this case foliage (Mendes, 1989; Lemos de Sá, 1991; Strier, 1991a; Chiarello and Galetti, 1994). At the Caratinga Biological Station, this ability has allowed $A$. fusca to reach a population density that is probably higher than that of the much smaller-bodied C. flaviceps (Mendes, 1989). Similarly high densities were recorded for $A$. fusca in a 250-ha forest remnant in São Paulo state (Chiarello and Galetti, 1994). Relying heavily on disturbed forest habitats, the population of Brachyteles at the same site has grown steadily over the past decade (Strier, 1991b) and a second population has survived in a degraded forest fragment of only 44 ha at a site further west (Lemos de Sá, 1991). The latter is smaller than eight of the 16 remnants visited during the present study.

Extrapolating from the results of the present study, at least 50 and as many as 100 isolated marmoset populations may still exist in the native forest habitat that appears on the $1: 1,000,000$ government survey map of the 
study region (see Diego et al., 1993). This is probably an underestimate because two of the sites at which marmosets were found are too small to appear on the map, which covers an area of $2800 \mathrm{sq} \mathrm{km}$. If the sites visited are a truly representative sample, a low minimum estimate of 300 populations may survive within the natural range of the species as defined by Ferrari and Mendes (1991) and Mendes (1993). Given an arbitrary minimum value of 10 individuals per population, the species's total population in the wild can be estimated to be at least 3000 , although 10,000 may be a more realistic, cautious figure. A similar extrapolation implies that $20-40$ populations of $A$. fusca survive in the study area.

Other things being equal, these numbers allow further room for 'cautious optimism' (Ferrari and Mendes, 1991) given that they would exceed most estimates of a minimum viable population (MacKinnon et al., 1986). Less optimistically, the reduction of the species to a large number of relatively small and effectively isolated populations has obviously deleterious implications in terms of inbreeding depression, although currently nothing is known of the genetic variability of the species.

A second, related problem resulting from this fragmentation of the population is the reduction of species integrity. Very little is known of the original distribution of C. flaviceps, and Coimbra-Filho and Mittermeier (1973) proposed, for example, that habitat degradation in Espírito Santo has favoured the expansion of Callithrix geoffroyi in this state. More recently, Ferrari and Mendes (1991) and Mendes (1993) reported apparent hybridization of C. flaviceps with C. geoffroyi at a number of sites in Espírito Santo, and with Callithrix aurita in Minas Gerais. One of the populations located in the present study was identified by Mendes (1993) as an aurita $\times$ flaviceps hybrid.

In addition to these potential problems, the taxonomic status of the flaviceps form itself remains unclear (Ferrari and Diego, 1993). While originally described as a true species (Thomas, 1903), flaviceps has been classified in recent years as a subspecies of both Callithrix jacchus
(Hershkovitz, 1977) and C. aurita (CoimbraFilho, 1990). The most recent and comprehensive review of Callithrix taxonomy (de Vivo, 1991) nevertheless supports the original classification (see also Mittermeier et al., 1992).

Clearly, successful conservation of the buffy-headed marmoset will demand far more groundwork in fields such as genetics, systematics and zoogeography. Given the basic ecological contrasts between regions, for example, there may be significant differences between marmosets from Espírito Santo and Minas Gerais and this would need to be taken into account in the planning of a conservation programme [see also Strier (1993) on Brachyteles]. In the short term, however, the management of available forest fragments and their primate populations may be the most effective conservation strategy for this and other Atlantic Forest species (e.g. Mendes and Chiarello, 1993; Chiarello and Galetti, 1994).

Basic management would include the translocation of animals between populations for the avoidance of inbreeding. It may also be possible to establish populations in appropriate tracts of at least 50 ha in which primates are now absent. This may be relatively straightforward in the case of C. flaviceps, which breeds rapidly and is not normally hunted, although more careful planning would be required for the larger, more vulnerable A. fusca and B. arachnoides (Strier, 1993).

Experience at the Fazenda Montes Claros and many other properties in Minas Gerais has demonstrated that landowners are generally sympathetic to the cause of conservation and would usually support such work on their land. In the longer term such management, if extended to the establishment of a reserve network, may prove to be far more practicable, efficient and cost-effective than captive-breeding and reintroduction programmes (Konstant and Mittermeier, 1982).

\section{Acknowledgements}

This study was supported by Conservation International and the Science Research Council (CNPq) of the Brazilian Government. We would like to thank Dida Mendes, Eduardo Veado and Sérgio 
Mendes, and the landowners of eastern Minas Gerais for their help and hospitality.

\section{References}

Chiarello, A.G. and Galetti, M. 1994. Conservation of the brown howler monkey in south-east Brazil. Oryx, 28, 37-42.

Coimbra-Filho, A.F. 1990. Sistemática, distribuição geográfica e situação atual dos símios brasileiros (Platyrrhini - Primates). Rev. Bras. Biol. 50, 1063-1079.

Coimbra-Filho, A.F. and Mittermeier, R.A. 1973. New data on the taxonomy of the Brazilian marmosets of the genus Callithrix, Erxleben 1777. Folio Primatol. 20, 241-264.

Diamond, J.M. 1975. The island dilemma: lessons of modern biogeographic studies for the design of natural reserves. Biol. Conserv. 7, 129-146.

Diego, V.H., Ferrari, S.F. and Mendes, F.D.C. 1993. Conservação do sagui-da-serra (Callithrix flaviceps): o papel de matas particulares. In $A$ Primatologia no Brasil, (eds M. E. Yamamoto and M. B. C. de Sousa), Vol. 4, pp. 129-137, Sociedade Brasileira de Primatologia, Natal.

Ferrari, S.F. 1991. Preliminary report on a field study of Callithrix flaviceps. In A Primatologia no Brasil, (eds A. B. Rylands and A. T. Bernades), Vol. 3, pp. 159-171. Sociedade Brasileira de Primatologia, Belo Horizonte.

Ferrari, S.F. and Diego, V.H. 1993. Rethinking the status of Callithrix flaviceps. Neotropical Primates, 1 (3), 2-3.

Ferrari, S.F. and Mendes, S.L. 1991. Buffy-headed marmosets ten years on. Oryx, 25, 105-109.

Hershkovitz, P. 1977. Living New World Monkeys (Platyrrhini), Vol. 1. University of Chicago Press, Chicago.

Hueck, K. 1972. As Florestas da América do Sul. Editora Poligono, São Paulo, Brazil.

Kleiman, D.G., Hoage, R.J. and Green, K.M. 1988. The lion tamarins, genus Leontopithecus. In Ecology and Behaviour of Neotropical Primates, (eds R. A. Mittermeier, A. B. Rylands, A. F. Coimbra-Filho and G. A. B. da Fonseca), Vol. 2, pp. 299-347. World Wildlife Fund-US, Washington DC.

Konstant, W.R. and Mittermeier, R.A. 1982. Introduction, reintroduction and translocation of neotropical primates, past experiences and future possibilities. Int. Zoo Ybk, 22, 69-77.

Lemos de Sá, R.M. 1991. A população de Brachyteles arachnoides (Primates, Cebidae) da Fazenda Esmeralda, Rio Casca, Minas Gerais. In $A$ Primatologia no Brasil, (eds A. B. Rylands and A. T. Bernades), Vol. 3, pp. 235-238. Sociedade Brasileira de Primatologia, Belo Horizonte.
MacKinnon, J., MacKinnon, K., Child, G. and Thornsell, J. 1986. Managing Protected Areas in the Tropics. IUCN, Gland, Switzerland.

Mendes, S.L. 1989. Estudo ecológico de Alouatta fusca (Primates, Cebidae) na Estação Ecológica de Caratinga, MG. Rev. Nord. Biol. 6, 71-104.

Mendes, S.L. 1993. Distribuição geográfica e estado de conservação de Callithrix flaviceps (Primates: Callitrichidae). In A Primatologia no Brasil, (eds M. E. Yamamoto and M. B. C. de Sousa), Vol. 4, pp. 139-154. Sociedade Brasileira de Primatologia, Natal.

Mendes, S.L. and Chiarello, A.G. 1993. A proposal for the conservation of the muriqui in the state of Espírito Santo, southeastern Brazil. Neotropical Primates, 1 (2), 2-4.

Mittermeier, R.A., Coimbra-Filho, A.F., Constable, I.D., Rylands, A.B. and Valle, C.M.C. 1982. Conservation of primates in the Atlantic Forest of eastern Brazil. Int. Zoo Ybk, 22, 2-17.

Mittermeier, R.A., Schwartz, M.B. and Ayres, J.M.C. 1992. A new species of marmoset, genus Callithrix Erxleben, 1777 (Callitrichidae, Primates) from the Rio Maués region, state of Amazonas, central Brazilian Amazonia. Goeldiana Zool. 14, 1-17.

Rylands, A.B. 1989. Sympatric Brazilian callitrichids: the black tufted-ear marmoset, Callithrix kuhli, and the golden-headed lion tamarin, Leontopithecus chrysomelas. J. Hum. Evol. 18, 679-695.

Soulé, M.E. and Simberloff, D. 1986. What do genetics and ecology tell us about the design of nature reserves? Biol. Conserv. 35, 19-40.

Strier, K.B. 1991a. Diet in one group of woolly spider monkeys, or muriquis (Brachyteles arachnoides). Am. J. Primatol. 23, 113-126.

Strier, K.B. 1991b. Demography and conservation of an endangered primate, Brachyteles arachnoides. Conserv. Biol. 5, 214-218.

Strier, K.B. 1993. Conservation of the muriqui in the state of Espírito Santo, southeastern Brazil. Neotropical Primates, 1 (3), 1-2.

Thomas, O. 1903. Notes on South American monkeys, bats, carnivores and rodents, with descriptions of new species. Ann. Mag. Nat. Hist. 12, 455-464.

de Vivo, M. 1991. Taxonomia de Callithrix Erxleben, 1777 (Callitrichidae, Primates). Fundação Biodiversitas, Belo Horizonte.

Stephen F. Ferrari, Departamento de Genética, Universidade Federal do Pará, Caixa Postal 8607, 66.075-150 Belém, PA, Brazil.

Vânia H. Diego, Departamento de Psicologia Experimental, Universidade Federal do Pará, Belém, Brazil. 